\title{
Commentary: The genius of Ake Senning
}

\section{Charles B. Huddleston, MD}

In 1959, Ake Senning reported on the remarkable correction of transposition of the great arteries (TGA) using a so-called atrial inversion technique. ${ }^{1}$ It is perhaps the most difficult operation to describe but not particularly difficult to perform. This innovative operation was a game-changing development in the treatment of congenital heart disease and likely served as a catalyst for further innovations that followed. Although no longer the treatment of choice for TGA, the principles of this operation are occasionally used, often in the setting of very complex congenital lesions in which separation of the pulmonary and systemic circulation is very challenging.

The article in this issue of the JTCVS Techniques describes 4 patients with TGA and total anomalous pulmonary venous return who presented very late for treatment; one was 22 years of age. ${ }^{2}$ The authors describe a clever way to deal with this problem in 3 of the patients (the fourth also had a ventricular septal defect and underwent arterial switch/ventricular septal defect closure and repair of total anomalous pulmonary venous return) using a modification of the pioneering technique described by Senning. These 3 patients survived and did well, at least in the short term.

Case reports such as this serve a couple of purposes. When successful, they provide information on an extremely rare congenital cardiac lesion and how one center approached this unusual lesion, should the opportunity arise in which this rare condition is seen again by others. Do I think that I will ever see a patient with TGA and total anomalous pulmonary venous return presenting at greater 1 year

From the St Louis University School of Medicine, St. Louis, Mo.

Disclosures: The author reported no conflicts of interest.

The Journal policy requires editors and reviewers to disclose conflicts of interest and to decline handling or reviewing manuscripts for which they may have a conflict of interest. The editors and reviewers of this article have no conflicts of interest.

Received for publication Aug 22, 2020; revisions received Aug 22, 2020; accepted for publication Aug 26, 2020; available ahead of print Sept 2, 2020.

Address for reprints: Charles B. Huddleston, MD, 1465 S Grand Blvd, St. Louis, MO 63104 (E-mail: Charles.huddleston@health.slu.edu).

JTCVS Techniques 2020;4:229

2666-2507

Copyright (C) 2020 The Authors. Published by Elsevier Inc. on behalf of The American Association for Thoracic Surgery. This is an open access article under the CC BY-NCND license (http://creativecommons.org/licenses/by-nc-nd/4.0/).

https://doi.org/10.1016/j.xjtc.2020.08.053 